\title{
Student Evaluations as a Measurement tool for Teaching Effectiveness and Student Satisfaction with the Food Science \& Technology Unit at a University Institution
}

\author{
D. Singh-Ackbarali *, M. Chan, R. Maharaj \\ University of Trinidad and Tobago, Bioscience Agriculture and Food Technology \\ Caroni North Bank Road, Piarco, Trinidad \& Tobago, W. I. \\ dimple.singh@utt.edu.tt
}

\begin{abstract}
Student evaluations are a useful means for gathering feedback about the overall delivery of courses and services and are used to inform staff and decision-makers about relevant issues that can impact the program and student learning. The success of the evaluations to ensure the maintenance of quality standards include: the validity of instrument to capture data on key indicators of effective teaching and service, the ability to be free from potential biases and to serve as a function of the instructor and unit to achieve usable data on the course delivery, administrative and laboratory services. The ongoing and cumulative evaluations over the course of 2014-2015 provided a body of evidence to determine whether or not intended outcomes are being achieved and how the programs and services can be improved. Results show the instructors and laboratory services exceeded student expectations and that age, gender, personality/teaching style had no major effect on students' ratings. Students were satisfied with the level of knowledge and expertise shown by their instructors. However analysis of data identified courses that could be improved if some instructors changed their teaching style, incorporated more technology in teaching, added more practical and interactive sessions and improved on effectiveness in sharing information and responding to questions. In some cases, the best way for improvement would be to change the instructor or work with instructors to develop new teaching styles and methods of delivery. The average rating received by the administrative services in the unit could be improved by dissemination of information and procedures, better coordination for student IDs, improving time to release student grades and having a unit representative available for part-time students. Effectiveness of the decisions and changes made in unit improvement can be measured by analyzing results of student evaluations for 20152016.
\end{abstract}

Keywords: Student evaluations, instructor rating, teaching strategy, course content.

\section{INTRODUCTION}

The Food Science and Technology (FS\&T) unit of The University of Trinidad and Tobago developed The Course Evaluation Form to gather feedback from students each term based on their academic experiences as well as to assess the quality of the services provided by the department. The form was categorized into four main areas to capture data based on evaluation of each individual course, its respective lecturer, the delivery of labs as applicable and lastly an evaluation of the department overall, particularly with respect to the administration and the students' general perspective on the quality of the service they received. The subsequent document provides an overview of the results achieved upon analysis of data gathered from each of the four areas following administration of the evaluation forms to students of each cohort within the FS\&T Unit.

Student course evaluations create a useful means for gathering feedback about the instruction and overall delivery of courses that can be used by the host institution to improve the standard at which a particular course or body of work is presented to students. This method of evaluation has been used successfully for several decades and has been the subject of multiple publications (W.E Addison \& J.R Stowell, 2012). Previous success with SETs (Student Evaluation of Teaching) garnered significant interest among researchers in North America and Canada and as a result of its proven effectiveness, has been increasingly utilized by universities worldwide (R.P. Perry \& J.C. Smart, 2007).

Students are directly affected by the method used by instructors to relay information to them, in terms of its validity, how comprehensible and clear it is communicated and its relevance to the course of 


\section{Singh-Ackbarali et al.}

study. Their perspective as silent partners in the evaluation process is necessary for the development and standardization of the teaching and learning relationship (P.A Gordon, 1998). However, while student outlook might be critical to the success of the evaluations and the improvement of the quality of the education they receive, it is the responsibility of the lecturers to use the feedback constructively so to facilitate an enhanced learning experience.

Based on information provided from foreign studies on the use of SETs (Student Evaluation of Teaching) and SEEQs (Students' Evaluations of Educational Quality), the success of student based evaluations of the teaching quality provided by lecturers in higher education is dependent on a number of factors. Firstly, because various factors compose the effective teaching-learning process, the evaluation should be suitable enough to capture the multi-dimensionality of the situation in order to deliver accurate analysis and thus evaluation forms should target multiple criteria for assessing teaching quality through evaluation of indicators associated with a sound teaching strategy (P.A. Gordon \& W.G Huitt, 1998). This ideology was established by Professor Herbert Marsh through the administration of one million $(1,000,000)$ surveys revising the multidimensionality of evaluations of instructor efficiency from 1983 to 1993. Another impacting factor on the evaluations was the stability of the lecturers over an extended period of time, meaning the consistency of the quality or standard of work that they provide to students remained relatively unchanged. This factor is important for consideration as in the interest of effective teaching and learning on the part of students, the quality of instruction they receive must remain constant and should be of the same quality to the students coming after (H.W Marsh, 1987). This was supported as part of the same study carried out in 1993 by Professor Herbert Marsh and further maintained by N. Hativa in his study in 1996 on University instructors' ratings profiles and their stability over time, and disciplinary differences.

Other factors contributing to the success of the evaluations include the validity of the evaluation instrument in capturing data on all indicators of effective teaching, the ability of the evaluation to be free from potential biases and maybe the most important factor, the ability of the evaluation to serve as a function of the instructor and not the course in order to achieve accurate data on the delivery of the course by the lecturer to ensure the maintenance of a high standard and consistency of the level of work conveyed (R.P. Perry \& J.C. Smart, 2007).

When developing the course evaluation form, what is also necessary is the identification of its primary purpose. As with SETs and SEEQs, the course evaluation can be used for formative and summative purposes (H.W Marsh, 2007). The ability to distinguish between the intended purpose of the evaluation would directly affect the information that is received, in terms of its effectiveness in improving the education standard as well as the person/persons that would benefit most upon analysis of the data collected i.e. students or the lecturers themselves. For example, had the evaluations been developed primarily for formative purposes, then the data collected would be used to assist in the development and improvement of the teaching-learning process as well as to aid self-improvement on the lecturers' part. In this way the evaluation targets specific aspects of the lecturer and his/her teaching style that (assuming the instructor is receptive to the feedback) would facilitate a smoother learning process for students. On the other hand, had the evaluations been developed primarily for summative purposes, the data collected would be used to assist with confirming/denying promotions, reappointments and considerations for salary increases, which majorly impacts the lecturer and the host institution and not necessarily the student. Therefore although the evaluations can be used for both purposes and the content can reflect information that would satisfy both formative and summative requirements, identifying the main objective of carrying out these evaluations while in development would significantly influence how effective they are in collecting data that achieves the objective regardless of the whether the information is used to placate a formative or summative motive (P.A. Gordon \& W.G Huitt, 1998).

Because of the need to quantify the effectiveness of the evaluation process, the benefits and limitations of the evaluation must also be considered. In previous studies conducted, it was the conclusion of multiple researchers that SETs (a similar method of evaluating lecturers to the FS\&T course evaluation) are a "valid, reliable, and worthwhile means of assessment" (J. E. Miller, 2009). However, despite this there are critics that argue that the subjective nature of this evaluation leaves it unreliable and open to bias. This opinion is shared among a number of instructors as they believe the evaluations, despite their efforts will produce the same results. For example, some believe that if they increase the level of standards or content in their course, it may result in worse evaluations from students, as it is not uncommon for students to detest a heavier workload than they are accustomed to. 
Student Evaluations as a Measurement tool for Teaching Effectiveness and Student Satisfaction with the Food Science \& Technology Unit at a University Institution

Another concern among lecturers is that the level of work, how it is conveyed or even their own competency in delivering the course material may not even be the subject of evaluation, instead however, students may evaluate them based on certain biases like personality, physical appearance, ethnicity, gender just to name a few and even situations where their grade is not what they were expecting (H.G. Murray, 2005). On the other side of this logic however, it is also worth noting the possibility of leniency on the part of lecturers with respect to grading and assignments in pursuit of positive ratings that, in turn take away from the academic content of courses (W.E Addison \& J.R Stowell, 2012).

With all factors considered, the implementation of any form of student based evaluation of lecturers is likely to have its associated benefits and limitations given the perspective of all parties involved. It is however the analysis of the collected data as well as the discretion of the persons responsible that will ensure the overall impact of the information, whether positive or negative as it seeks to achieve a higher quality standard of work from lecturers to their respective students.

\section{OBJECTIVES OF THE FoOd SCIENCE AND TECHNOLOGY STUdENT EVALUATION}

The evaluation strategy was designed with the following purposes in mind: capturing data to inform, improve and to prove. The results from the evaluation process should provide information that can be used to determine whether or not intended outcomes are being achieved and how the programs can be improved. The evaluation was also designed to inform departmental faculty and other decisionmakers about relevant issues that can impact the program and student learning. The ongoing and cumulative evaluations over the course of one academic year should provide a body of evidence to improve programs and prove effectiveness of changes and recommendations.

The information gathered from the evaluations should be able to answer the following questions:

How well are students being served by academics and administration?

How can the unit improve?

How can courses and teaching procedures be refined to enhance student learning?

What is the department's overall teaching effectiveness?

Does age and number of years teaching experience correlate to student ratings?

Does faculty who demonstrate higher positive self-esteem, energy and enthusiasm tend to get higher ratings?

Does full time University faculty receive higher ratings than part time external instructors?

Is there a difference in the ratings between male and female instructors?

\section{METHOD}

Packages with hard copies of the evaluations were prepared for each course delivered during the academic year. These were assigned to the different class representatives to distribute during the last month of each academic term. Evaluations were completed anonymously by students in the classroom assigned to each course and in the absence of the course instructor. Once the evaluations were completed the class representatives collected these and returned to the Programme Officer of the FS\&T unit.

Information was then transferred onto an excel work sheet and the data was treated and analysed, see tables below which illustrate the compilation and treatment of information from the evaluations for the three terms in the academic year 2014 to 2015.

Table1. Example of how student scores/ratings were compiled for evaluation of instructor (this is just an excerpt of the ten areas covered in the Instructor evaluation), where 1 was assigned if the instructor is below expectation, 2 is assigned if instructor is average and 3 is assigned if the instructor exceeds expectations.

\begin{tabular}{|l|l|l|l|l|l|l|}
\hline $\begin{array}{l}\text { Studen } \\
\text { t No. }\end{array}$ & $\begin{array}{l}\text { Knowl } \\
\text { edge }\end{array}$ & $\begin{array}{l}\text { Commu } \\
\text { nication }\end{array}$ & $\begin{array}{l}\text { Delive } \\
\text { rs info }\end{array}$ & $\begin{array}{l}\text { Exams were related } \\
\text { to course content }\end{array}$ & $\begin{array}{l}\text { Stimulates } \\
\text { critical thinking }\end{array}$ & $\begin{array}{l}\text { Demonstrates respect } \\
\text { for students }\end{array}$ \\
\hline 1 & 1 & 1 & 1 & 1 & 1 & 3 \\
\hline 2 & 3 & 3 & 3 & 3 & 3 & 2 \\
\hline 3 & 3 & 3 & 2 & 1 & 3 & 2 \\
\hline 4 & 2 & 2 & 2 & 1 & 2 & 3 \\
\hline
\end{tabular}




\section{Singh-Ackbarali et al.}

For the numerical data collected, the median scores were calculated; a higher median score translates to a higher (more positive) rating on the behaviour or variable in question. The percentage of responses under each category was also calculated as this can yield a different picture of teaching than the one median score and may provide information that can better describe student's perceptions.

Table2. Example of how written comments were analysed

\begin{tabular}{|l|l|l|l|}
\hline Student Comments & + & - & Conclusions/change \\
\hline Content enhanced learning of subject matter & $\checkmark \checkmark \checkmark \checkmark$ & $\checkmark$ & \\
\hline Satisfaction with instructor delivery & $\checkmark$ & $\checkmark \checkmark \checkmark \checkmark$ & Change delivery style \\
\hline Satisfaction with instructor punctuality & $\checkmark \checkmark \checkmark \checkmark \checkmark$ & & \\
\hline Instructor was engaging & $\checkmark$ & $\checkmark \checkmark \checkmark \checkmark$ & Change delivery style or instructor \\
\hline
\end{tabular}

While student's comments may be rich with insights and suggestions, it is often difficult to make sense of them in ways that lead to identifiable change. This is compounded by the often-contradictory nature of written comments and the disorganized way that they are presented and read. Structure was imposed on these comments by sorting them into categories. The most basic categorization was by strengths and weaknesses, with student comments listed under the appropriate heading. Next a minus sign (-) was placed next to negative comments and a plus sign (+) next to the positive comments. These were then tallied as a way to highlight and summarize the comments and provide direction for change.

The following was considered or assumed facts about student ratings that were considered when interpreting the results for improvement:

i. Student ratings were generally reliable and valid;

ii. The instructor not the course was the primary determinant of the student ratings;

iii. Ratings from a variety of courses was used to form a general picture of an instructor's overall teaching effectiveness;

iv. Classes in which student provide higher ratings are generally the classes from which students learn more;

v. Numerical student ratings tend to overlap considerably with written comments;

vi. Age, and years of teaching experience do not generally correlate to student ratings;

vii. Instructor gender is generally not associated with student ratings;

viii. Demonstrated higher positive self-esteem, energy and enthusiasm tend to get higher ratings;

ix. Class size moderately influences student ratings with students in smaller classes giving higher ratings;

x. Student motivation and expected grades are correlated to ratings with students who are more motivated and who work harder and those who expect higher grades providing higher ratings;

xi. Academic field makes a difference - students in math and engineering courses give lower ratings than those in science and business type courses,

xii. Students give higher ratings in difficult courses where they have to work hard;

xiii. Adequate instructor-level reliability may be obtained when ratings are aggregated across at least seven classes;

xiv. Ratings from courses with fewer than 15 students should be viewed conservatively.

\section{ReSUlts}

For the three terms of the academic year 2014 to 2015, 39 courses were offered (courses were counted once even though they were offered more than once over the academic year and for both full time and part time classes) and 22 instructors delivered these courses.

\subsection{Evaluation of Course}

Students were asked yes or no questions on if they thought the course was applicable to their area of study and if the course enhanced their learning in the subject matter. They were also asked to give recommendations on how the course could be improved. 
Student Evaluations as a Measurement tool for Teaching Effectiveness and Student Satisfaction with the Food Science \& Technology Unit at a University Institution

Out of all the courses offered, 14 of these had responses that the course was not applicable to the student's area of study. These 14 courses were mainly foundations courses, math and engineering based courses, non-science courses or courses where there was a lot of independent research needed and group work assigned. For 7 of these 14 courses, students suggested that the instructor be changed and for the remaining 7 that the delivery could be improved either by style in which instructor presented material or by adding more practical sessions and field trips, and that the course should be offered in a longer term.

\subsection{Interesting Findings from Evaluations based on the Type of Course Taught}

Some of the comments from the evaluations are presented below for the different categories of subjects - business, mathematics, foundation, science and technology

Table3. Business Type Courses

BUSI3012 Business Management Term1 2014-2015 and BUSI1002 Business Management and Entrepreneurship Term 2 2014-2015 (delivered by 2 different instructors)

\begin{tabular}{|l|l|l|l|}
\hline Category of comments & + & - & Conclusions/change \\
\hline $\begin{array}{l}\text { Content was relevant and enhanced } \\
\text { Learning of Subject Matter }\end{array}$ & $\checkmark \checkmark \checkmark \checkmark \checkmark \checkmark \checkmark \checkmark$ & $\checkmark \checkmark \checkmark$ & Change content delivered \\
\hline Satisfaction with instructor delivery & $\checkmark$ & $\checkmark \checkmark \checkmark \checkmark$ & Change teaching strategy \\
\hline Instructor was engaging & & $\checkmark \checkmark \checkmark \checkmark \checkmark \checkmark \checkmark \checkmark \checkmark \checkmark$ & $\begin{array}{l}\text { Change Instructor and/or } \\
\text { style }\end{array}$ \\
\hline
\end{tabular}

Table4. Courses Heavy in Mathematics

MATH1030 Mathematics for Agriculture, Food \& Forestry Term 1 2014-2015, STAT1002 Statistics and Research Methodology - Term 2 2014-2015, PHYS1003 Physics Term 3 2014-2015. The same instructor delivered MTH1030 and STAT1002

\begin{tabular}{|l|l|l|l|}
\hline Category of comments & + & - & Conclusions/change \\
\hline \begin{tabular}{l} 
Content was relevant $\begin{array}{l}\text { and enhanced Learning } \\
\text { and } \\
\text { of Subject Matter }\end{array}$ \\
\hline $\begin{array}{l}\text { Satisfaction with } \\
\text { instructor delivery }\end{array}$
\end{tabular} & $\begin{array}{l}\checkmark \checkmark \checkmark \checkmark \checkmark \text { not change course content } \\
\checkmark \checkmark \checkmark\end{array}$ & $\begin{array}{l}\text { Keep instructor and/or delivery } \\
\text { style for MATH1030 } \\
\text { Change the instructor and/or } \\
\text { delivery style for STAT1002 } \\
\text { Improve Delivery for PHYS1003 }\end{array}$ \\
\hline Instructor was engaging & $\checkmark \checkmark \checkmark$ & $\begin{array}{l}\text { No Change for MATH1030 and } \\
\text { PHYS1003 } \\
\text { Change the instructor and/or style } \\
\text { for STAT1002 }\end{array}$ \\
\hline
\end{tabular}

Table6. Foundation Courses

BIOL1007 Biology for Food Science \& Agriculture - Term 1 2014-2015

CHEM1002 Introductory to Chemistry/ Mathematics - Term 1 2014-2015

COMM1002 Communications Term 1 2014-2015 (taught by 2 different instructors)

HSEV1005 Intro to Health and Safety and Environment Term 1 2014-2015

\begin{tabular}{|l|l|l|l|}
\hline Category of comments & + & - & Conclusions/change \\
\hline $\begin{array}{l}\text { Content was relevant } \\
\text { and enhanced Learning } \\
\text { of Subject Matter }\end{array}$ & $\begin{array}{l}\checkmark \checkmark \checkmark \checkmark \checkmark \checkmark \checkmark \checkmark \checkmark \checkmark \\
\text { Satisfaction with }\end{array}$ & $\begin{array}{l}\checkmark \checkmark \checkmark \checkmark \checkmark \checkmark \checkmark \\
\checkmark \checkmark \checkmark \checkmark \checkmark \checkmark\end{array}$ & $\begin{array}{l}\text { Do not change course content for } \\
\text { BIOL1007, COMM1002 }\end{array}$ \\
\hline $\begin{array}{l}\text { instructor delivery } \\
\text { Instructor was engaging }\end{array}$ & $\checkmark \checkmark \checkmark \checkmark \checkmark \checkmark \checkmark$ & $\checkmark$ & $\begin{array}{l}\text { Keep instructor and/or delivery style } \\
\text { for BIOL1007 and CHEM1002, } \\
\text { change may be needed for } \\
\text { COMM1002. Might need to review } \\
\text { for HSEV1005 }\end{array}$ \\
\hline
\end{tabular}


D. Singh-Ackbarali et al.

\begin{tabular}{|l|l|l|l|}
\hline $\begin{array}{l}\text { Duration of Class } \\
\text { session and/or semester } \\
\text { was sufficient }\end{array}$ & $\checkmark$ & & $\begin{array}{l}\text { No change in class time or semester } \\
\text { for BIOL1007 }\end{array}$ \\
\hline $\begin{array}{l}\text { Timely delivery of } \\
\text { material, } \\
\text { Lectures and grades }\end{array}$ & & $\checkmark \checkmark \checkmark$ & $\begin{array}{l}\text { Change means by which course } \\
\text { deliverables are completed to ensure } \\
\text { timely delivery to students for } \\
\text { COMM1002 }\end{array}$ \\
\hline $\begin{array}{l}\text { Labs and field trips } \\
\text { were sufficient }\end{array}$ & $\checkmark$ & & $\begin{array}{l}\text { No additional labs or field trips for } \\
\text { BIOL1007 }\end{array}$ \\
\hline $\begin{array}{l}\text { Group work was } \\
\text { adequate }\end{array}$ & $\checkmark \checkmark$ & $\checkmark$ & $\begin{array}{l}\text { No additional group work for } \\
\text { BIOL1007 and COMM1002 }\end{array}$ \\
\hline
\end{tabular}

Table7. Science and Technology Courses

FOOD1002 Basic Food Chemistry - Term 2 2014-2015 (taught be two different instructors)

FOOD1003 Basic Food Microbiology Term 1 \& 2 2014-2015 (taught be three different instructors)

FOOD1001 Introduction to Food Technology Term 2 2014-2015

FOOD 3012 Postharvest Processing Technology - Term 2 2014-2015

\begin{tabular}{|c|c|c|c|}
\hline Category of comments & + & - & Conclusions/change \\
\hline $\begin{array}{l}\text { Content was relevant and } \\
\text { enhanced Learning of } \\
\text { Subject Matter }\end{array}$ & $\begin{array}{l}\checkmark \checkmark \checkmark \checkmark \checkmark \checkmark \checkmark \checkmark \checkmark \checkmark \checkmark \\
\checkmark \checkmark \checkmark \checkmark \checkmark \checkmark \checkmark \checkmark \checkmark \checkmark\end{array}$ & & $\begin{array}{l}\text { Do not change course } \\
\text { content for FOOD1002, } \\
\text { FOOD1003 }\end{array}$ \\
\hline $\begin{array}{ll}\text { Satisfaction } & \text { with } \\
\text { instructor delivery } & \end{array}$ & 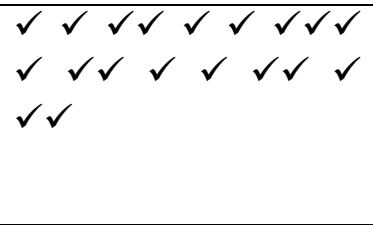 & $\begin{array}{l}\checkmark \checkmark \checkmark \checkmark \checkmark \checkmark \\
\checkmark \\
\checkmark \checkmark \checkmark\end{array}$ & $\begin{array}{l}\text { Keep instructor and/or } \\
\text { delivery style for } \\
\text { FOOD1002, FOOD1003. } \\
\text { Change instructor for } \\
\text { FOOD1001 }\end{array}$ \\
\hline Instructor was engaging & $\begin{array}{l}\checkmark \checkmark \checkmark \checkmark \checkmark \checkmark \checkmark \checkmark \checkmark \checkmark \\
\checkmark \checkmark \checkmark\end{array}$ & $\checkmark \checkmark \checkmark \checkmark \checkmark$ & $\begin{array}{l}\text { No change for FOOD1002. } \\
\text { FOOD1003 } \\
\text { Change instructor for } \\
\text { FOOD1001 }\end{array}$ \\
\hline $\begin{array}{l}\text { Duration of } \begin{array}{l}\text { Class } \\
\text { session and/or } \\
\text { was sufficient }\end{array} \\
\text { waster }\end{array}$ & & $\sqrt{ }$ & $\begin{array}{l}\text { No change in class time or } \\
\text { semester for FOOOD } 1002\end{array}$ \\
\hline $\begin{array}{l}\text { Timely delivery of } \\
\text { course material, Lectures } \\
\text { and grades }\end{array}$ & & $\checkmark \checkmark$ & $\begin{array}{l}\text { Delivery of material can be } \\
\text { improved from FOOD3012 }\end{array}$ \\
\hline $\begin{array}{l}\text { Labs and field trips were } \\
\text { sufficient }\end{array}$ & $\checkmark \checkmark \checkmark$ & $\checkmark \checkmark \checkmark$ & \begin{tabular}{lr}
\multicolumn{2}{l}{ No additional labs or field } \\
trips for & FOOD1002. \\
improvement & for \\
FOOD1001 & and \\
FOOD3012 & \\
\end{tabular} \\
\hline $\begin{array}{lll}\text { Group } & \text { work } & \text { was } \\
\text { adequate } & & \\
\end{array}$ & $\checkmark$ & $\checkmark \checkmark \checkmark$ & $\begin{array}{l}\text { No additional group work } \\
\text { for FOOD1002, } \\
\text { improvement needed for } \\
\text { one of the classes delivered } \\
\text { for FOOD1003 }\end{array}$ \\
\hline
\end{tabular}

\subsection{Evaluation of Instructors}

Instructors were graded out of 3 for 10 categories, where 1 was assigned if the instructor is below expectation, 2 is assigned if instructor is average and 3 is assigned if the instructor exceeds expectations.

Generally the instructors that provided service to FS\&T unit all exceeded expectations in all ten categories according to the medians and percentages (illustrated in Figure 1) calculated from the combined students responses. 
Student Evaluations as a Measurement tool for Teaching Effectiveness and Student Satisfaction with the Food Science \& Technology Unit at a University Institution

Below Expectation average Exceeded Expectation

Is knowledgeable of the Subject Matter $(n=478)$

Communicated and presented the course content and materials clearly and in a well organized...

Constantly delivers updated information related to the course $(n=474)$

Did the exams covered readings and lectures related to the course content $(n=467)$

Encouraged his/her students to ask questions and express their viewpoints on matters related to the...

Stimulates critical thinking and analysis amongst his/her students $(n=475)$

Provides timely feedback regarding his/her students' progress in the course, grades etc. $(n=475)$

Demonstrates respect for students $(n=478)$

Arrives to class on time $(n=476)$

Completes his/her class session on time $(n=472)$

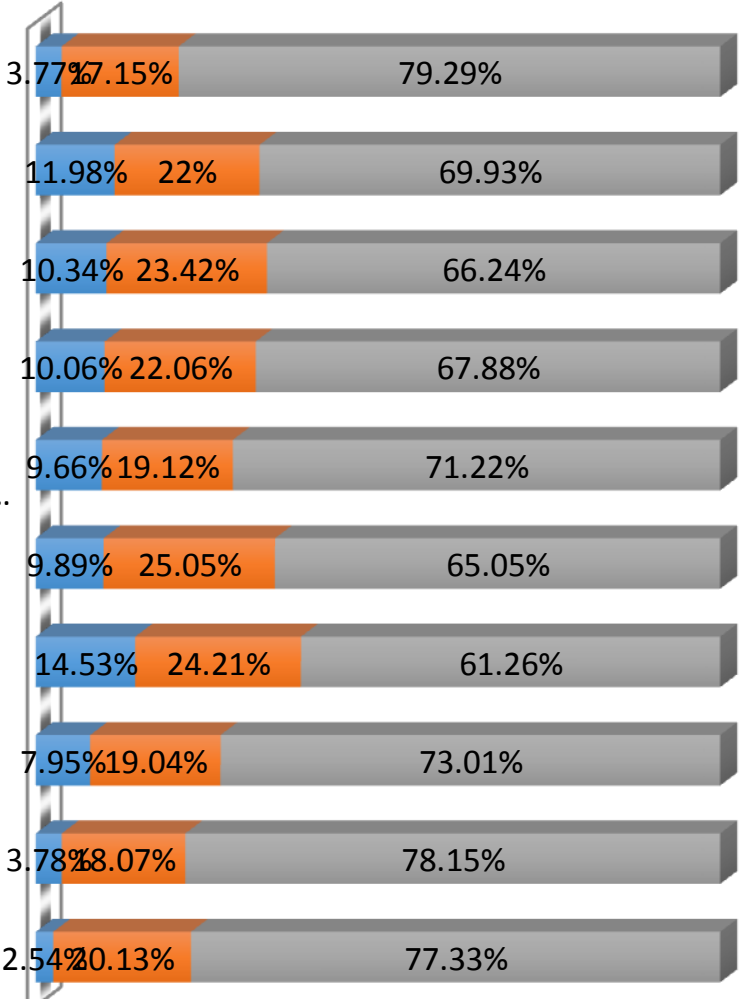

Figure1. Satisfaction with Instructional Effectiveness

Some of the comments that came out of some of the individual instructor evaluations included:

Improve on response to student emails

Improve on providing course map early in the term so students can prepare themselves for class

Very patient, knowledgeable and presents information well

Very enthusiastic

Table1. Comparison between University FS\&T Instructor Rating, University Non-FS\&T Instructor Rating and External/Part Time (PT) Instructor Rating

\begin{tabular}{|l|l|l|l|l|l|}
\hline Category & $\begin{array}{l}\text { FS\&T } \\
\text { Staff }\end{array}$ & $\begin{array}{l}\text { Other } \\
\text { University Staff }\end{array}$ & $\begin{array}{l}\text { PT } \\
\text { Instructor }\end{array}$ & Mean & $\begin{array}{l}\text { Std. } \\
\text { Dev. }\end{array}$ \\
\hline Is knowledgeable of the Subject Matter & 2.80 & 2.60 & 2.70 & 2.71 & 0.13 \\
\hline $\begin{array}{l}\text { Communicated and presented the course content and } \\
\text { materials clearly and in a well-organized manner? }\end{array}$ & 2.80 & 2.40 & 2.50 & 2.55 & 0.23 \\
\hline $\begin{array}{l}\text { Constantly delivers updated information related to } \\
\text { the course }\end{array}$ & 2.80 & 2.30 & 2.40 & 2.53 & 0.28 \\
\hline $\begin{array}{l}\text { Did the exams covered readings and lectures related } \\
\text { to the course content }\end{array}$ & 2.90 & 2.30 & 2.50 & 2.56 & 0.27 \\
\hline $\begin{array}{l}\text { Encouraged his/her students to ask questions and } \\
\text { express their viewpoints on matters related to the } \\
\text { lectures }\end{array}$ & 2.80 & 2.50 & 2.60 & 2.65 & 0.16 \\
\hline $\begin{array}{l}\text { Stimulates critical thinking and analysis amongst } \\
\text { his/her students }\end{array}$ & 2.80 & 2.50 & 2.50 & 2.59 & 0.18 \\
\hline $\begin{array}{l}\text { Provides timely feedback regarding his/her students' } \\
\text { progress in the course, grades etc. }\end{array}$ & 2.60 & 2.40 & 2.30 & 2.43 & 0.14 \\
\hline Demonstrates respect for students & 2.80 & 2.40 & 2.60 & 2.61 & 0.21 \\
\hline Arrives to class on time & 2.80 & 2.80 & 2.60 & 2.72 & 0.13 \\
\hline Completes his/her class session on time & 2.80 & 2.60 & 2.70 & 2.68 & 0.14 \\
\hline
\end{tabular}




\section{Singh-Ackbarali et al.}

It appears that the internal FS\&T instructors received a higher rating than all other instructors for all ten categories, followed by external/part time (PT) instructors for seven of the categories. The standard deviation was less than one for each category therefore it can be said that there is not major difference or very little variation in the ratings between internal FS\&T staff, other University staff and external/PT instructors. All instructors got a high rating, above average rating for each of the ten categories.

Table2. Comparison between Male and Female Instructor Rating

\begin{tabular}{|l|l|l|l|l|}
\hline Category & $\begin{array}{l}\text { Female } \\
\text { Instructors }\end{array}$ & $\begin{array}{l}\text { Male } \\
\text { Instructors }\end{array}$ & $\begin{array}{l}\text { Mea } \\
\text { n }\end{array}$ & $\begin{array}{l}\text { Std. } \\
\text { Dev. }\end{array}$ \\
\hline Is knowledgeable of the Subject Matter & 2.66 & 2.79 & 2.73 & 0.09 \\
\hline $\begin{array}{l}\text { Communicated and presented the course content and materials clearly } \\
\text { and in a well-organized manner? }\end{array}$ & 2.56 & 2.46 & 2.51 & 0.07 \\
\hline Constantly delivers updated information related to the course & 2.54 & 2.38 & 2.46 & 0.11 \\
\hline $\begin{array}{l}\text { Did the exams covered readings and lectures related to the course } \\
\text { content }\end{array}$ & 2.53 & 2.52 & 2.53 & 0.01 \\
\hline $\begin{array}{l}\text { Encouraged his/her students to ask questions and express their } \\
\text { viewpoints on matters related to the lectures }\end{array}$ & 2.63 & 2.68 & 2.65 & 0.03 \\
\hline Stimulates critical thinking and analysis amongst his/her students & 2.58 & 2.46 & 2.52 & 0.08 \\
\hline $\begin{array}{l}\text { Provides timely feedback regarding his/her students' progress in the } \\
\text { course, grades etc. }\end{array}$ & 2.45 & 2.26 & 2.36 & 0.13 \\
\hline Demonstrates respect for students & 2.62 & 2.58 & 2.60 & 0.03 \\
\hline Arrives to class on time & 2.80 & 2.49 & 2.64 & 0.22 \\
\hline Completes his/her class session on time & 2.77 & 2.57 & 2.67 & 0.14 \\
\hline
\end{tabular}

It appears that the female instructors received a higher rating than male instructors for eight of the ten categories. The standard deviation was less than one for each category therefore it can be said that there is not major difference or very little variation in the ratings between female and male instructors. All instructors got an above average rating for each of the ten categories.

\subsection{Evaluation of FS\&T Laboratory Services and Facilities}

Laboratory subunit of FS\&T were graded out of 3 for 3 categories, where 1 was assigned a rating of below expectation, 2 is assigned a rating of average and 3 is assigned rating of exceeds expectations.

The quality of lab services and the lab facilities exceeded expectations in all categories according to the medians and percentages (illustrated in Figure 3) calculated from the combined students responses.

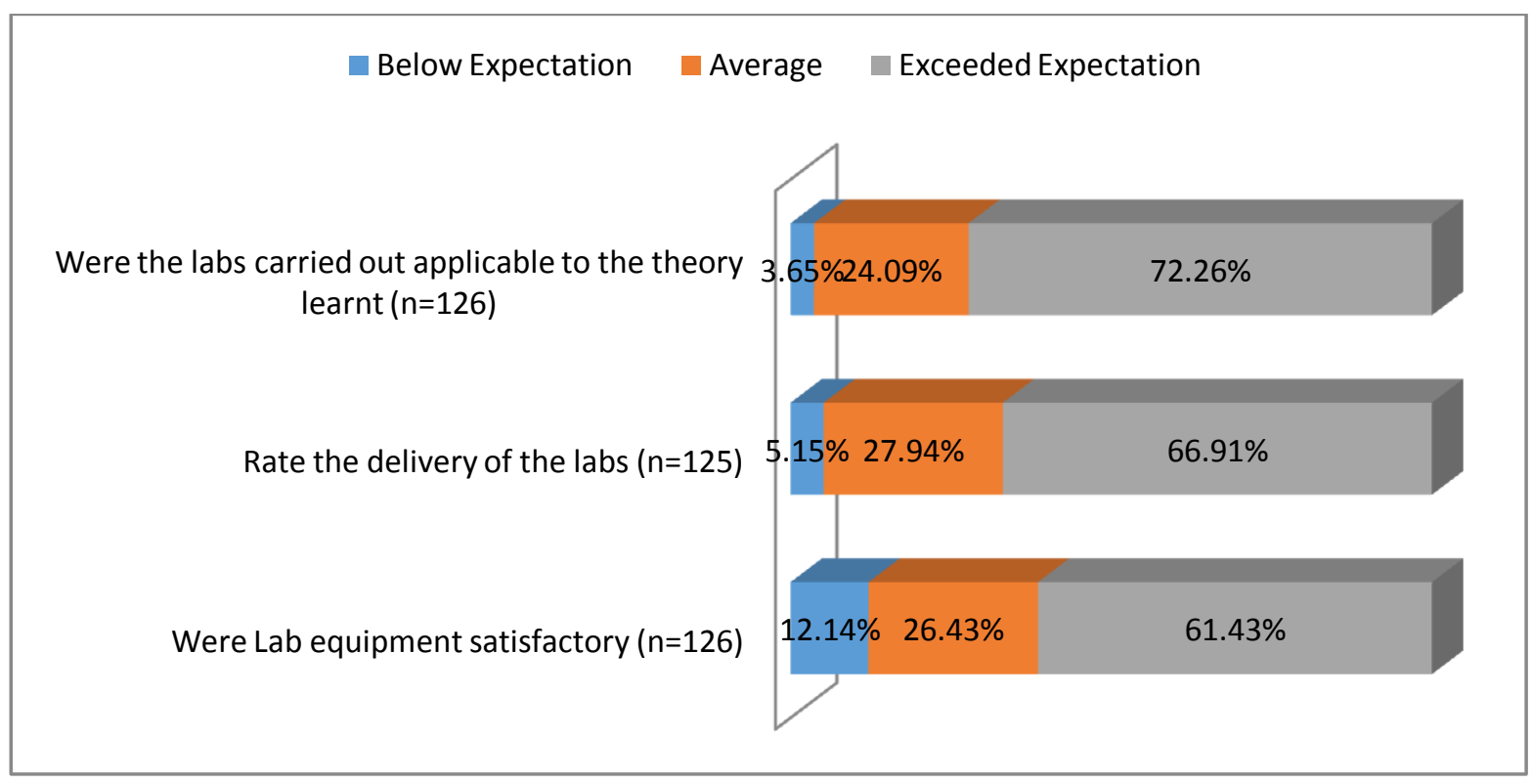

Figure2. Quality of Laboratory Facilties

Some of the comments from this section of the evaluation included:

More laboratory equipment needed

Larger lab space needed 
Student Evaluations as a Measurement tool for Teaching Effectiveness and Student Satisfaction with the Food Science \& Technology Unit at a University Institution

\subsection{Evaluation of Services from FS\&T Administration}

The quality of service from the administrative subunit of FS\&T were graded out of 3 for 2 categories, where 1 was assigned a rating of below expectation, 2 is assigned a rating of average and 3 is assigned rating of exceeds expectations.

The administrative services was average in all categories according to the medians and percentages (illustrated in Figure 4) calculated from the combined students responses.

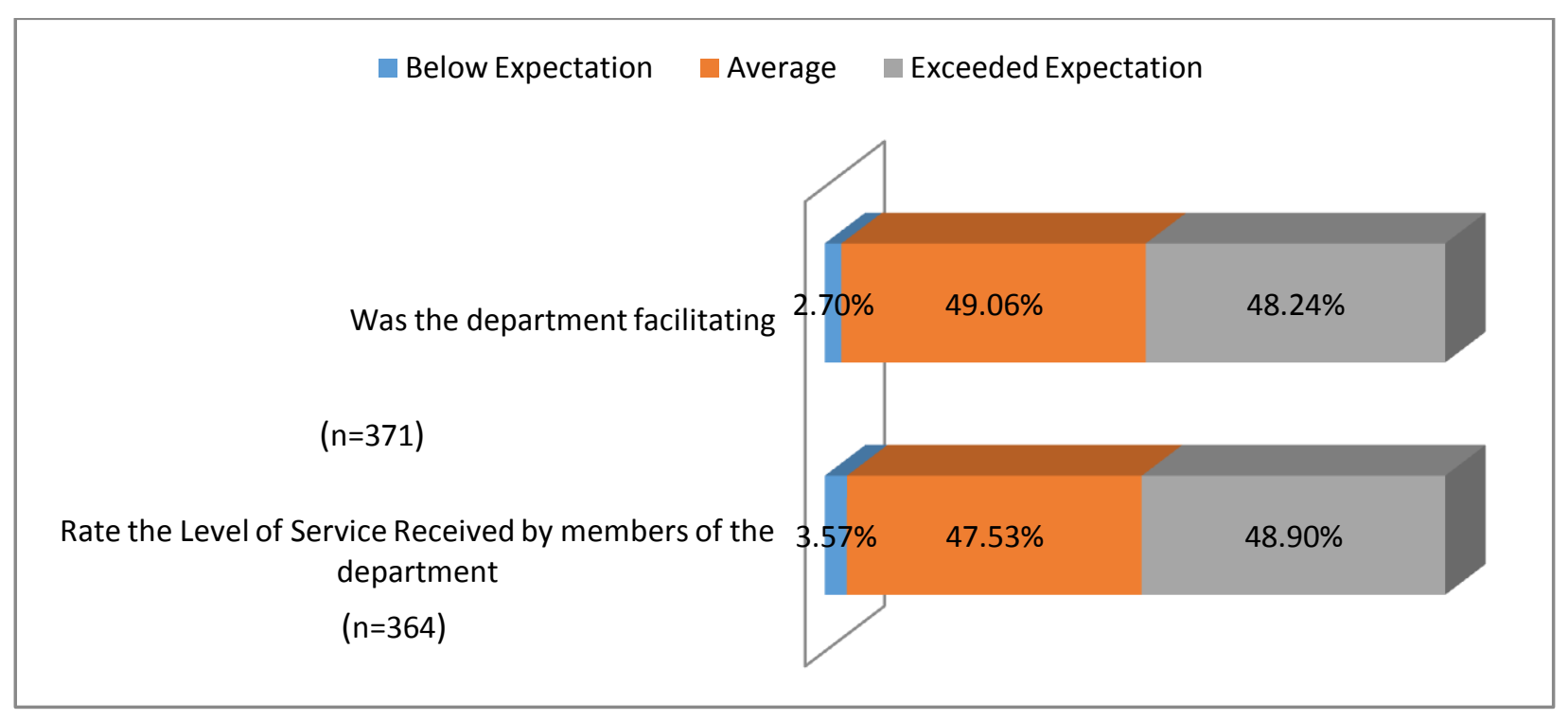

Figure3. Quality of Service from the Department

Some of the comments from this section of the evaluation included:

More support at the Valsayn campus/to part time students

Improvement needed on the delivery of student IDs

Improvement needed in the timely release of grades

Improve in choice/assignment of instructors

There has been improvement

Improvement seen between term 1 and term 2

\section{DISCUSSION AND CONCLUSION}

Most students failed to see the applicability of, and gave lower ratings for; the foundations courses, engineering courses, business courses and courses with a lot of practical group work. These were also the courses that students generally did not perform well in and also the courses with very large class sizes. Most of our students did not have a strong Mathematics, English Language or Physics background before they entered the University and so the unfamiliar content posed extra challenges for them to successfully complete and appreciate these courses. This result is in line with past findings on research done on student evaluations of teaching (SET); courses that are difficult and especially those that fall under English language, Business, Mathematics and Engineering usually received medium low and lowest ratings (S. Stodolsky, 1984 and W.E. Cashin, 1990). Student's expectations of grades have also been identified as an influencing factor in SETs (D. Perkins et al., 1990 and R.L. Johnson \& V.K. Christian, 1990). Lower SET scores are usually given if students do not expect to get good grades. Unfamiliar and difficult content coupled with larger class sizes as these were common courses for several programmes may have negatively influenced the course ratings and students' perception. The students who did not see the applicability and gave lower scores to those courses that required group work may not have had great group dynamics and had challenges in completing these courses successfully or were not confident in the grades that would be awarded. This conception of non-applicability to the area of study could have also been attributed to the instructor style and delivery and/or the short space of time the course was delivered in, which lead to dissatisfaction with the course and thus the choice of rating them as non-applicable to area of study. 


\section{Singh-Ackbarali et al.}

The next time that these courses are offered different instructors may be selected to teach or if another instructor cannot be sourced the FS\&T unit together with the class representative will work with the instructor to come up with new methods of delivery and teaching style that would be more receptive by the students, by increasing practical sessions and tutorials or even adding zero credit introductory workshops to introduce some of the unfamiliar topics before students register for these courses.

The results of the SETs showed that students were very satisfied with the instructional effectiveness. There were no significant differences in rating for instructors who were from the FS\&T unit to those from other University units and external part time instructors. There were few gender differences in the rating for the different categories. The raw data may have appeared to favour female instructors especially in areas related to sensitivity and on concern with student level of preparedness and progress. Ratings of male and female teachers did not differ significantly in this or for other dimensions of teaching.

Generally, instructor age and years of teaching experience had no correlations with student ratings. However, where weak correlations were found they were negative, older instructors that did not use technology in their lectures or outside of the classroom received lower ratings. Instructors who had less experience in teaching did not receive lower ratings compared to experienced instructors. This is the opposite of findings on past research on student evaluations, where it was found that first time instructors received lower ratings compared to experienced professors and that this was probably due to the differences in teaching skills, first time instructors are most likely still learning how to teach (J.A. Centra, 2009; S.P. Smith \& D. P. Kinney, 1992).

Thus the decisions on staffing based on source of instructor, gender and age would not be affected by SET ratings.

Limited research that has been done on instructor personality variables on SETs, however the research that has been conducted all show a correlation between the two (P.M. Simpson \& J.A. Siguaw, 2000, W.M. Williams \& S.J. Ceci 1997, D.E. Clayson, 1999 and D.L. Jackson et al., 1999). Enthusiastic instructors that are personable can receive favourable student ratings regardless of how well they know their subject matter (D.L. Jackson et al., 1999). The results of the SET did not support these past findings as instructors who received high ratings also had student comments that indicated that while instructors were knowledgeable they were very boring, unenthusiastic and uninspiring, SETs with these comments also suggested that the instructor be changed. What matters is using the comments from the evaluation on how the instructor's personal characteristics are manifested in the classroom and how the behaviors the instructor exhibits when teaching can be altered to enhance the instructor's teaching effectiveness. The SET that was administered had no way of gathering data to determine if the instructor makes a difference in student learning for courses that are taught by multiple persons.

The services of the FS\&T laboratory unit and staff have generally exceeded the expectations of students however areas for improvement including, increasing the lab space the amount of pieces and type of equipment have been mentioned in the SETs. The unit has sought permission to expand physical infrastructure and has developed a laboratory binder with possible laboratory exercises related to the theory for the different courses. The material and apparatus sections from the lab manual and proper planning of lab exercises have allowed continuous update to the lab inventory to ensure that that equipment availability and resources are improved.

The FS\&T administrative services and staff was rated as average and students commented that while some improvement did occur between term 1 and 2 of the academic year, further improvement is needed in certain areas. The areas of improvement that were identified also involved other university units such as examinations unit, student services and maintenance services. Orientations with instructors and students, increase in administrative staff, deployment of support staff from FS\&T unit to the other campus where courses are taught and increased communications between university units have been some of the tactics employed to increase student satisfaction in this area.

The SET instrument can be improved by including a section that can help determine if the instructor makes a difference in student learning in courses that are taught by multiple persons. Analysis of the results collected from student evaluations for academic year 2015 to 2016 can assist in determining if the departmental changes and decisions were effective in improving the unit and the services offered.

In general, student ratings tend to be statistically reliable, valid, and relatively free from bias more so than any other data used for faculty evaluation. However, student ratings are only one source of data about teaching effectiveness and must be used in combination with multiple sources of information if 
one wishes to make a judgment about all of the components of university teaching. This paper summarizes the general conclusions and decisions that can be made to improve the university unit from the results of the student evaluations.

\section{REFERENCES}

[1] J.E. Miller, (2009) Ph.D. Dissertation: Student Evaluations of Teaching: Perceived Merits and Disadvantages, and Suggestions for Improving the Assessment Method. Harding University

[2] Effective Evaluation of Teaching; A Guide for Faculty and Administrators. Edited by Mary E Kite

[3] H.W. Marsh, (1987). Students Evaluation of University Teaching: Research Findings, Methodological Issues, and Directions for Future Research

[4] H.W. Marsh, (1996) Students Evaluations of University Teaching: Dimensionality, Reliability, Validity, Potential, Bias and Usefulness. Oxford University

[5] R.P. Perry and J.C. Smart (eds.), The Scholarship of Teaching and Learning in Higher Education: An Evidence-Based Perspective, 319-383. 2007 Springer

[6] P.A. Gordon, W.G. Huitt, (1998) Ph.D. Student Evaluations of College Instructors. Valdosta State University

[7] W.E. Cashin, (1995). Student Ratings of Teaching: The Research Revisited. Update of "Student Ratings of Teaching: A Summary of the Research. Kansas State University. Center for Faculty Evaluation and Development

[8] H.G. Murray. Student Evaluation of Teaching: Has It Made a Difference? Department of Psychology University of Western Ontario. Paper presented at the Annual Meeting of the Society for Teaching and Learning in Higher Education Charlottetown, Prince Edward Island, June 2005.

[9] H.W. Marsh, (2007) University Of Sydney, Australia. Touron, Javier. Universidad de Navarra, Spain and Wheeler, Barbara. University of Sydney, Australia. Students' Evaluations of University Instructors: The Applicability of American Instruments in a Spanish Setting.

[10] H.W. Marsh. Students' Evaluations of University Teaching: Ratings of Teachers, Universities and Departments. Oxford University. Presentation at HEA Conference May $19^{\text {th }} 2011$

[11] S. Stodolsky, (1984), "Teacher evaluation: the limits of looking", Educational Researcher, November, pp. 11-18.

[12] W. Cashin, (1990), "Students do rate different academic fields differently", in Theall, M. and Franklin, J. (Eds), Student Ratings of Instruction: Issues for Improving Practice, Jossey-Bass, San Francisco, CA.

[13] R.L. Johnson and V.K. Christian, (1990), "Relation of perceived learning and expected grade to rated effectiveness of teaching", Perceptual and Motor Skills, Vol. 70, pp. 479-82.

[14] D. Perkins, D. Gueri, and J. Schleh, (1990), "Effects of grading standards information, assigned grade, and grade discrepancies on student evaluations", Psychological Reports, Vol. 66,pp. 63542.

[15] S.P. Smith, and D.P. Kinney, (1992), "Age and teaching performance", Journal of Higher Education, Vol. 63 No. 3, pp. 282-302.

[16] J. A. Centra, (2009). Differences in responses to the Student Instructional Report: Is it bias? Princeton, NJ: Educational Testing Service.

[17] P.M. Simpson, and J.A. Siguaw, (2000), "Student evaluations of teaching: an exploratory study of the faculty response", Journal of Marketing Education, Vol. 22 No. 3, pp. 199-213.

[18] W.M. Williams and S.J. Ceci, (1997), “'How'm I doing?' Problems with student ratings of instructors and courses", Change, Vol. 29 No. 5, pp. 12-23.

[19] D.E. Clayson, (1999), "Students' evaluation of teaching effectiveness: some implications of stability", Journal of Marketing Education, Vol. 21, April, pp. 68-75.

[20] D.L. Jackson, C.R. Teal, S.J. Raines and T.R. Nansel, (1999), "The dimensions of students' perceptions of teaching effectiveness", Educational and Psychological Measurement, Vol. 59 No. 4, pp. 580-96. 